\title{
Т.Н. ЭРИВАНЦЕВА,
}

К.М.Н., заведующая отделом медицины и медицинской техники, Федеральный институт промышленной собственности, г. Москва, РФ, ru-patent@mail.ru

\section{口ЦЕНКА ПЕРСПЕКТИВ ПРЕОДОЛЕНИЯ ИМПОРТОЗАВИСИМОСТИ В УСЛОВИЯХ РЕАЛИЗАЦИИ НАЦИОНАЛЬНОГО ПРОЕКТА «НАУКА» ПО ДАННЫМ ПАТЕНТНОГО АНАЛИЗА}

УДК 330.3

Эриванцева Т.Н. Оценка перспектив преодоления импортозависимости в условиях реализации национального проекта «Наука» по данным патентного анализа (Федеральный институт промышленной собственности, Бережковская наб., д. 30, корп. 1, г. Москва, Россия, 125993)

I Аннотация. Согласно целевым показателям, используемым в проекте паспорта национального проекта

1. «Наука», Российская Федерация к 2024 г. должна занять 5-ое место в мире по количеству патентных

I заявок на изобретения. Проанализирована существующая в настоящее время патентная активность

I. отечественных разработчиков в области устройств для введения лекарств в организм или для нанесения их

I на кожный покров человека. Представлен сравнительный анализ изобретательской активности отечественных

I и зарубежных разработчиков. Показано, что в рамках такого приоритетного направления как «переход

I к высокотехнологичному здравоохранению и технологиям здоровьесбережения» (п. 20-в Стратегии научно-

I технологичного развития Российской Федерации), отечественные разработчики демонстрируют крайне низкую

I патентную активность по сравнению с показателями высокоразвитых стран.

I Ключевые слова: национальный проект «Наука», паспорт, число заявок на патент, шприцы, катетеры.

DOI 10.22394/2410-132X-2018-4-4-261-271

- Цитирование публикации: Эриванцева Т.Н. (2018) Оценка перспектив преодоления импортозависимости в условиях I реализации национального проекта «Наука» по данным патентного анализа // Экономика науки. Т. 4. №4. С. 261-271.
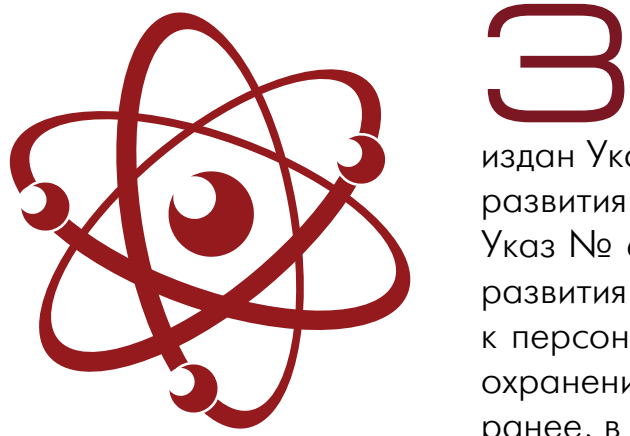

а последние годы был утвержден ряд документов, направленных на модернизацию и повышение эффективности отечественного сектора генерации знаний. В 2016 г. был издан Указ Президента РФ «О Стратегии научно-технологического развития Российской Федерации» (№ 642 от 01.12.2016 г., далее Указ № 642), который определил приоритеты научно-технического развития на ближайшие 10-15 лет, в числе которых - переход к персонализированной медицине, высокотехнологичному здравоохранению и технологиям здоровьясбережения [1, п. 20 в]. Годом ранее, в 2015 г., в связи с курсом на снижение зависимости от импорта, законодательно были утверждены положения, регламентирующие планы мероприятий по импортозамещению, в том числе, и в отрасли медицинской промышленности. Одним из таких документов является приказ Минпромторга России № 655 от 31 марта 2015 г. «Об утверждении плана мероприятий по импортозамещению в отрасли медицинской промышленности Российской Федерации» (далее Приказ № 655) [2]. Согласно этому документу, медицинские изделия, к которым относятся, в том числе, и медицинские инструменты, были классифицированы, и для каждого класса был (c) Т.Н. Эриванцева, 2018 г. установлен свой плановый показатель доли импорта до 2020 г. Из 
приказа следует, что на 2015 г. доля импорта составляла до 80-100\% по большинству медицинских изделий, а к 2020 г. должна снизиться до $10-20 \%$, а по некоторым изделиям - импорта не должно быть вообще.

Тема технологического суверенитета получила развитие и в Указе Президента Российской Федерации № 204 от 07 мая 2018 г. «О национальных целях и стратегических задачах развития Российской Федерации на период до 2024 года» [3]. В перечне целевых показателей, содержащихся в проекте паспорта национального проекта «Наука», содержится следующий: «место Российской Федерации по удельному весу в общем числе заявок на получение патента на изобретение, поданных в мире по областям, определяемых приоритетами научно-технологического развития».

Охраняемая интеллектуальная собственность (ИС) является эффективным инструментом, обеспечивающим монопольное положение правообладателя на территории действия охранных документов, предоставляет возможность реализовать максимальные объемы продаж и получения прибыли на монополизированных рынках, повышает деловую репутацию и стоимость компании, открывает возможности использования новых форм предпринимательской деятельности (франчайзинг, инжиниринг и др.).

Без патентования своих разработок российские разработчики, сами того не ведая, могут производить контрафакт и неожиданно для себя оказаться в зоне повышенного риска, когда через суды их могут обанкротить или навязать невыгодные для отечественного производителя лицензии. Это связано с тем, что, начиная производить какой-либо продукт, большинство отечественных разработчиков не считает целесообразным предварительно проводить патентные исследования, патентовать свою продукцию, как и в принципе разрабатывать маркетинговую политику. Однако именно по результатам патентного исследования возможно спрогнозировать вероятные риски развития конфликтных ситуаций с конкурентами и иными заинтересованными лицами, а также скорректировать технические характеристики производимого продукта для соблюдения как собственных интересов, так и интересов конкурентов. Процедура патентования позволит получить объективную оценку патентоспособности разработки, т.к. в результате проведения экспертизы по существу объекта патентования оценивается мировая новизна разработки. Экспертиза объекта патентования включает в объем поиска как отечественные, так и зарубежные патентные документы, а также иные сведения, ставшие общедоступными до даты приоритета заявки на объект патентной охраны.

Проблемы, обусловленные несоблюдением правил обращения с результатами интеллектуальной деятельности, в настоящее время масштабно проявляются в фармацевтической отрасли. Многочисленные судебные тяжбы с иностранными патентообладателями тормозят выход, как на собственный рынок, так и на зарубежные рынки, отечественных лекарственных препаратов.

Для оценки достижимости целевых показателей перечисленных стратегических документов был выполнен патентный анализ в технологической области, связанной с разработкой устройств для введения лекарств или нанесения их на кожный покров человека. Выбор именно этой группы медицинских изделий обусловлен их массовым использованием как в медицинской практике, так и населением в повседневной жизни.

Глубина поиска составила 10 лет. В поиск были включены следующие страны: страны EC - Германия, Дания, Австрия, Франция, Италия, а также США, Япония, Китай, РФ, Израиль, Великобритания.

Результаты исследования получены с использованием ресурсов базы данных QPAT (www.Qpat.com) французской компании Questel (www.Questel.com) по различным поисковым запросам, отражающим направления развития исследуемого объекта.

Для целей поиска была использована Международная патентная классификация (МПК). МПК является средством для единообразного в международном масштабе классифицирования патентных документов. МПК организована по принципу от общего к частному и содержит классы, характеризующие отдельные 
группы инструментов, реализующих узконаправленную функцию.

Медицинские инструменты, являющиеся предметом настоящего исследования, классифицированы в разделе А - «Удовлетворение жизненных потребностей человека», в классе A61 - «Медицина и ветеринария; гигиена», подклассе А61M - «Устройства и приспособления для введения лекарств в организм или для нанесения их на кожный покров человека».

Адаптированная для удобства восприятия трактовка используемых классов МПК, представлена ниже:

A61M 3 - Медицинские спринцовки; ирригаторы,
А61M 5 - Устройства для подкожного, внутрисосудистого и внутримышечного введения сред в организм (шприцы),

А61M 11 - Разбрызгиватели или распылители для лечебных целей,

А61M 13 - Устройства для вдувания или распыления порошков с лечебными или дезинфекционными целями,

А61M 15 - Ингаляторы,

А61M 25 - Катетеры.

$\mathrm{Ha}$ первом этапе исследования была определена динамика патентной активности в мире по перечисленным выше классам МПК за последние 20 лет. Полученные результаты представлены на рис. 1-6.

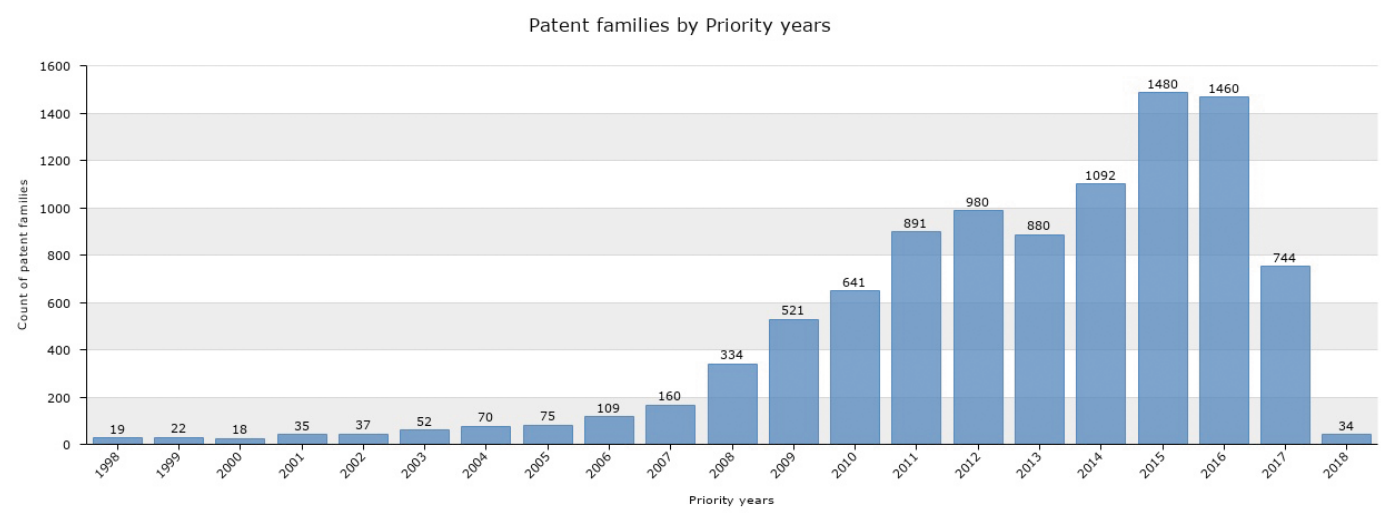

๑ Questel 2018

Рис. 1. Динамика роста числа патентных документов по классу А61 М3 «Медицинские спринцовки; ирригаторы» за 1997-2017 гr.

Источник: БД Orbit, данные актуальны на 10.06.2018 г.

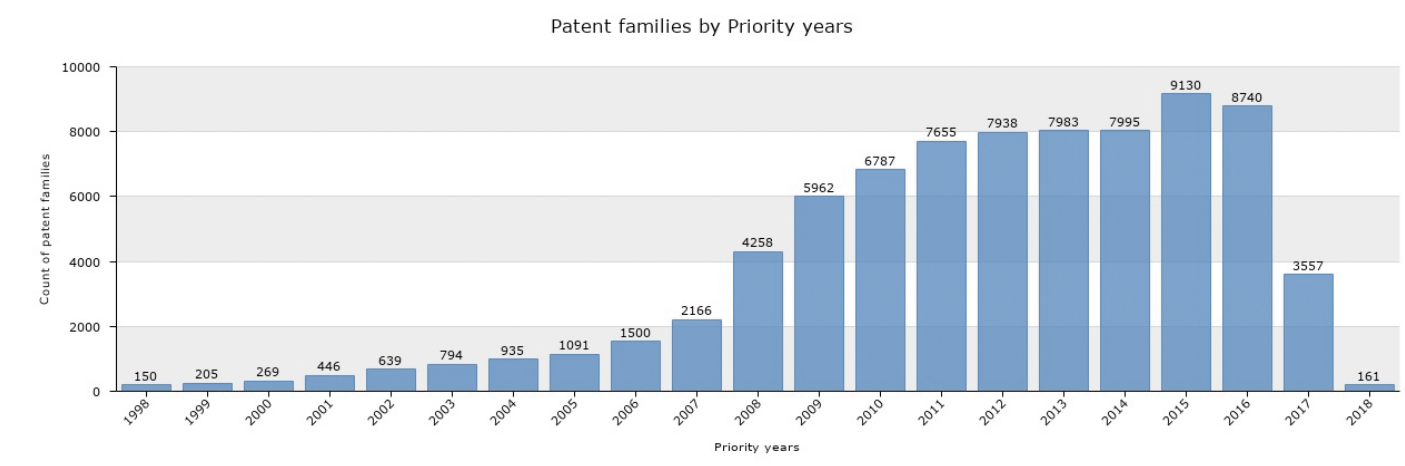

๑ Questel 2018

Рис. 2. Динамика роста числа патентных документов по классу А61 М5 «Устройства для подкожного, внутрисосудистого и внутримышечного введения сред в организм (шприцы) » за 1997-2017 rr.

Источник: БД Orbit, данные актуальны на 10.06.2018 г. 
Patent families by Priority years

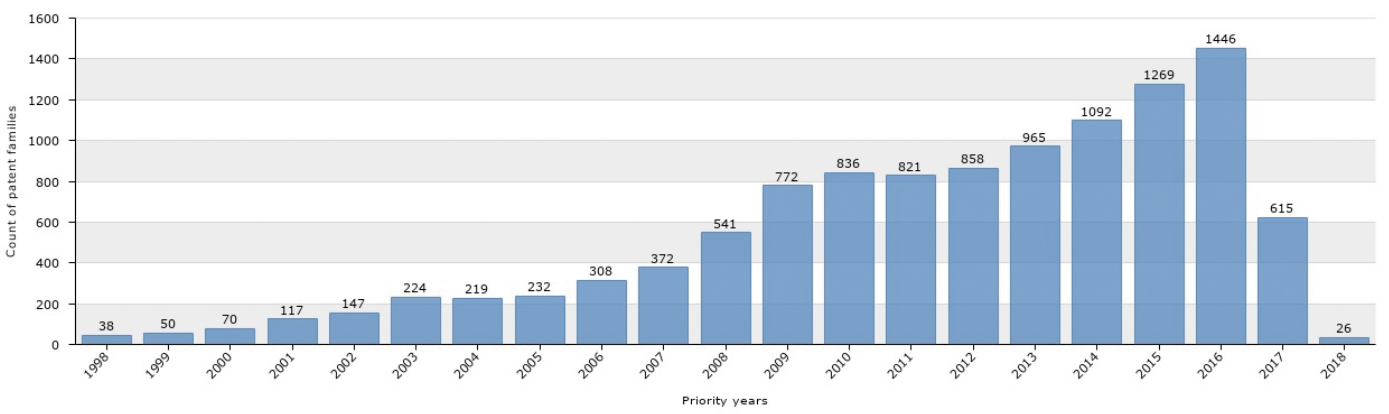

Рис. 3. Динамика роста числа патентных документов по классу А61м11 «Разбрызгиватели или распылители для лечебных целей» за 1997-2017 rr. Источник: БД Orbit, данные актуальны на 10.06.2018 г.

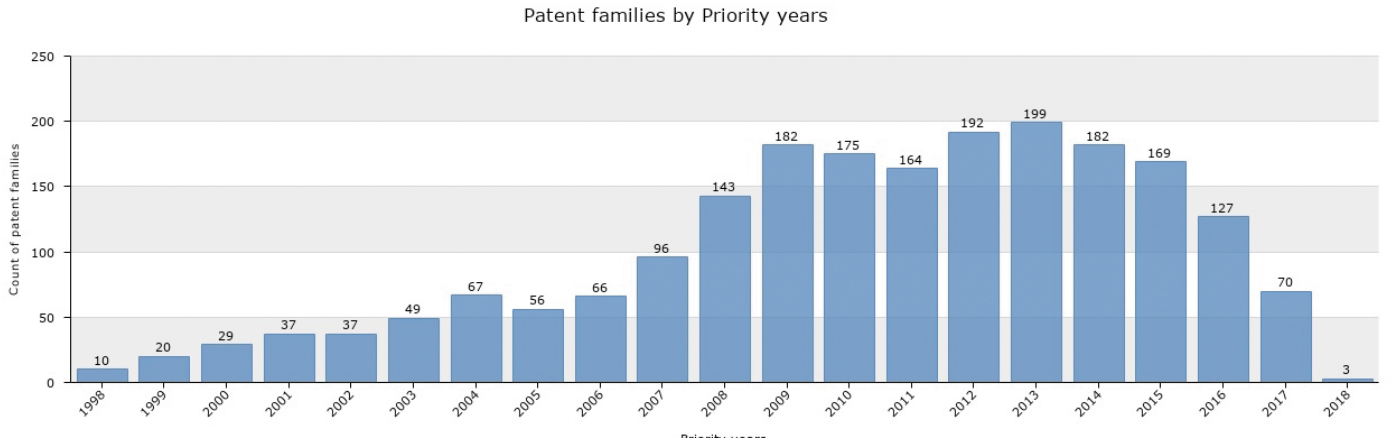

๑) Questel 2018

Рис. 4. Динамика роста числа патентных документов по классу А61м13 «Устройства для вдувания или распыления порошков с лечебными или дезинфекционными целями» за 1997-2017 rr.

Источник: БД Orbit, данные актуальны на 10.06.2018 г.

Patent families by Priority years

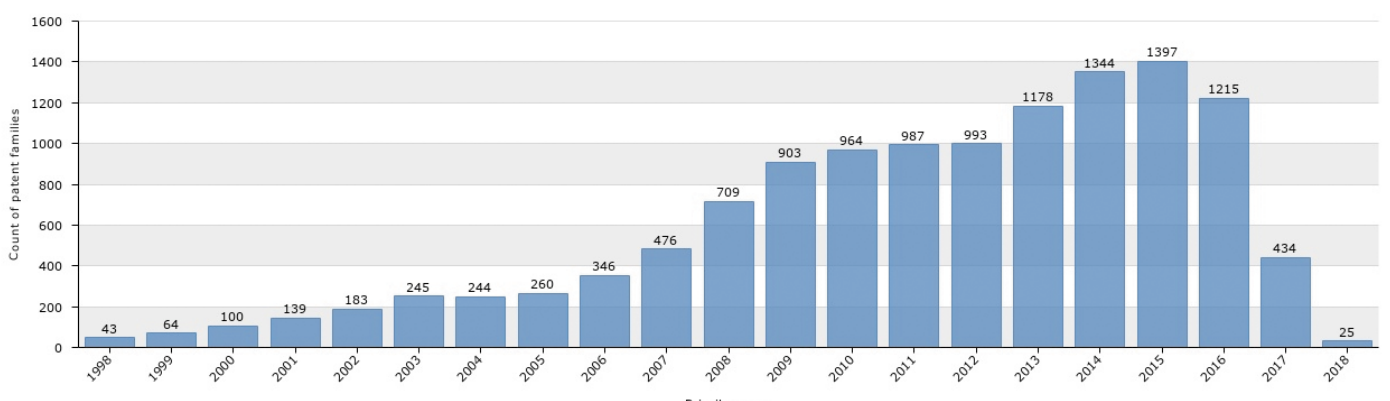

๑ Questel 2018

Рис. 5. Динамика роста числа патентных документов по классу А61M15 «Ингаляторы» 3а 1997-2017 rr.

Источник: БД Orbit, данные актуальны на 10.06.2018 г. 
Patent families by Priority years

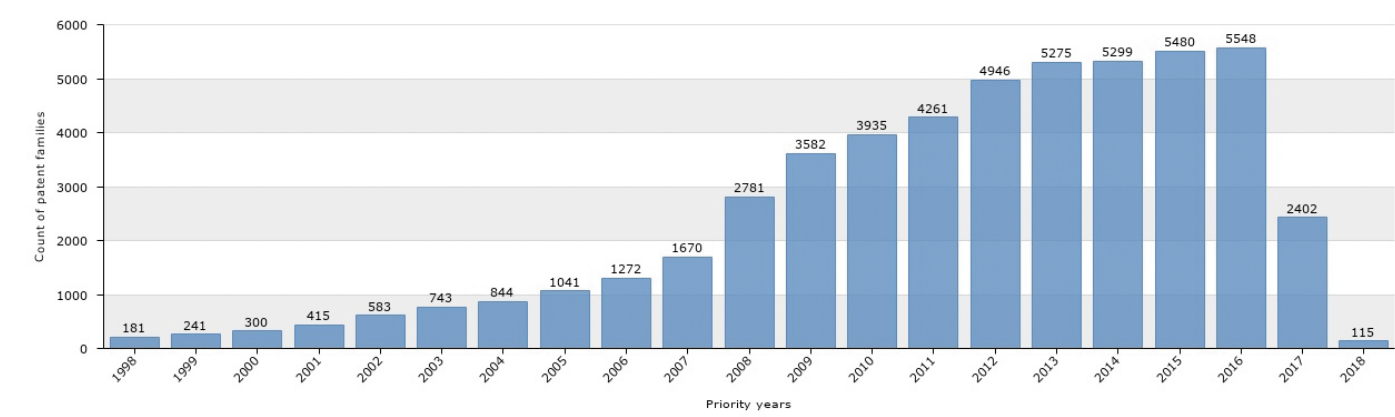

๑ Questel 2018

\section{Рис. 6. Динамика роста числа патентных документов по классу А61M25 «Катетеры» за 1997-2017 rr.}

Источник: БД Orbit, данные актуальны на 10.06.2018 г.

Из анализа полученных данных следует, что в течение последних 10 лет наблюдается активная разработка во всех исследуемых направлениях. При этом на момент написания статьи, статистические данные за 2017 г. загружены не в полном объеме.

В тоже время, стоит обратить внимание на динамику патентной активности, касающейся шприцев, разбрызгивателей, катетеров, стентов. В 2006-2008 гг. произошел резкий скачок по количеству поданных патентных документов, причем в дальнейшем положительная динамика сохранилась. Сравнительные данные по количеству поданных патентных документов за 10 лет представлены в табл. 1.

Отраженная в табл. 1 тенденция патентования таких медицинских изделий, как шприцы, разбрызгиватели, катетеры, демонстрирует уверенность разработчиков в востребованности новых технических решений и, по сути, отражает рыночный потенциал данного класса медицинских инструментов.

Далее была детально проанализирована тенденция патентования в течение 5 последних лет двух изделий с наибольшим увеличением количества подаваемых патентных документов - шприцы и катетеры. Как уже отмечалось выше, МПК организована по принципу от общего к частному и содержит классы, характеризующие отдельные группы инструментов, реализующих узконаправленную функцию. Оценка распределения патентных документов по группам классов МПК, позволяет более детально исследовать тенденции развития класса в целом, т.к. конкретный класс, указывает на то, что именно разработано изобретателем в той или иной области.

Было выявлено, что наибольшее количество патентных документов в области разработки шприцев за 5 лет распределено по четырем классам (табл. 2).

Ключевые патентообладатели в мире в области разработки шприцев представлены на рис. 7.

Стоит обратить внимание на то, что в списке компаний-патентообладателей (рис. 7) со значительным отрывом лидирует фармацевтическая компания Sanofi (743 патентный

Таблица 1

Динамика поступления патентных документов за 2007-2016 rг.

\begin{tabular}{|l|c|c|}
\multicolumn{1}{|c|}{$\begin{array}{c}\text { Тип медицинского } \\
\text { изделия }\end{array}$} & $\begin{array}{c}\text { Период кратного увеличения патентной } \\
\text { активности }\end{array}$ & $\begin{array}{c}\text { Кратность увеличения патентных } \\
\text { документов за 10 лет (2006-2016 гг.) }\end{array}$ \\
\hline Шприцы & 2007 г. (2166 ед.) - 2008 г. (4258 ед.) & в 6 раз (с 1500 до 8740$)$ \\
\hline Разбрызгиватели & 2008 г. (541 ед.) - 2009 г. (772 ед.) & в 5 раз (с 308 до 1446) \\
\hline Катетеры & 2008 г. (2781 ед.) -2009 г. (3582 ед.) & в 4 раза (с 1272 до 5548$)$ \\
\hline
\end{tabular}

Источник: БД Orbit, данные актуальны на 10.06.2018 г. 


\section{Распределение патентных документов в области разработки шприцев $3 а 5$ лет}

\begin{tabular}{|l|l|c}
\hline \multicolumn{1}{|c|}{ Класс МПК } & \multicolumn{1}{|c|}{ Наименование класса МПК } & $\begin{array}{c}\text { Доля } \\
\text { разработок }\end{array}$ \\
\hline А61M5/14 & устройства для вливания, например под действием силы тяжести (насосы) & $14,95 \%$ \\
\hline А61M5/32 & инъекционные иглы;детали для присоединения игл со шприцем или втулкой & $7,17 \%$ \\
\hline А61M5/168 & $\begin{array}{l}\text { средства управления потоком лекарственной или питательной среды или дози- } \\
\text { рования, например капельные дозаторы или счетчики капель }\end{array}$ & $6,89 \%$ \\
\hline А61M5/31 & детали шприцев без игл для инъекции под действием струи & $6,39 \%$
\end{tabular}

Источник: БД Orbit, данные актуальны на 10.06.2018 г.

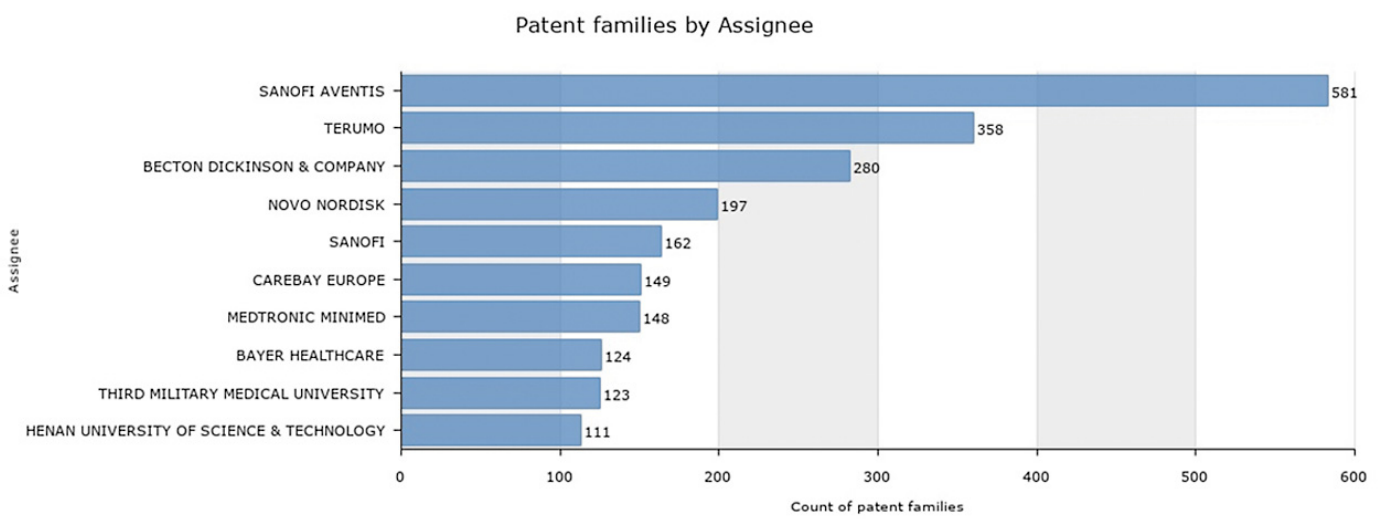

Рис. 7. Ключевые патентообладатели в мире в области разработки шприцев

Источник: БД Orbit, данные актуальны на 10.06.2018 г.

документ за 5 лет (из которых 581 документ получен на Sanofi-Aventis и 162 документа - на Sanofi). Sanofi (до лета 2011 г. Sanofi-Aventis) французская фармацевтическая компания, которая является одной из лидирующих мировых фармацевтических корпораций. Одним из основных видов деятельности компании Sanofi является производство инсулина.

Данный факт наглядно демонстрирует, что фармацевтическая отрасль за рубежом уделяет внимание комплексной защите своих разработок, патентуя не только составы препаратов, но и устройства, и способы их введения, увеличивая тем самым объем рынка, на который распространяется их монополия.

Наибольшее количество патентных документов в области разработки катетеров за 5 лет проклассифицировано по классам (табл. 3).

Ключевые патентообладатели в мире в области разработки катетеров представлены на рис. 8.

\section{Распределение патентных документов по классам МПК в области разработки катетеров за 5 лет}

\begin{tabular}{c|l|c}
\hline Класс МПК & \multicolumn{1}{|c}{ Наименование класса МПК } & Доля разработок \\
\hline А61M25/10 & $\begin{array}{l}\text { баллонные катетеры (но не раздуваемые баллоны для размещения стен- } \\
\text { тов или стентов-графтов) }\end{array}$ & $10,86 \%$ \\
\hline А61M25/01 & $\begin{array}{l}\text { введение, направление, продвижение, размещение или удерживание } \\
\text { катетеров }\end{array}$ & $7,95 \%$ \\
\hline А61M25/02 & держатели катетеров, например на теле & $7,54 \%$ \\
\hline
\end{tabular}

Источник: БД Orbit, данные актуальны на 10.06.2018 г. 
Patent families by Assignee

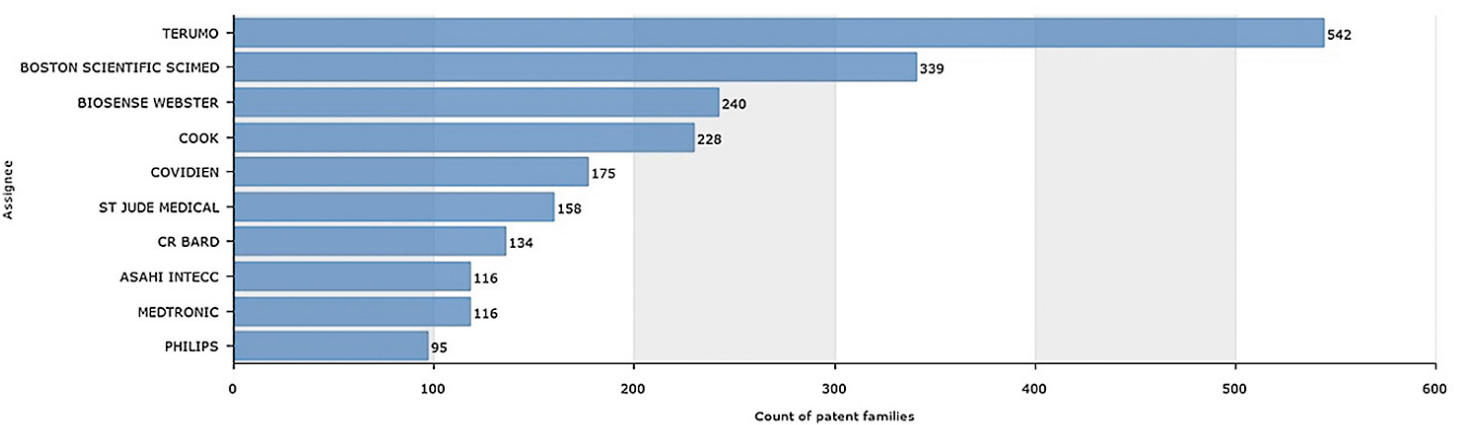

Рис. 8. Ведущие мировые патентообладатели в области разработки катетеров Источник: БД Orbit, данные актуальны на 10.06.2018 г.

Патентованием катетеров, согласно данным, приведенным на рис. 8, в отличие от шприцев, занимаются компании, специализирующиеся на производстве медицинских изделий. Так, например, Terumo (Япония) - лидер в области патентования катетеров, является японской компанией, осуществляющей выпуск изделий для ангиографии, кардиологии, кардиохирургии и лабораторной диагностики.

Далее была проанализирована ситуация, складывающаяся с патентованием катетеров и шприцев на территории РФ. Поиск проводился по БД ФИПС (http://new.fips.ru/). Глубина поиска 5 лет.
За исследуемый период зарегистрировано 338 изобретений, касающихся шприцев (речь о шприцах любого применения, не только инсулиновых), из которых 90\% (303 патента) принадлежит нерезидентам, и 121 изобретение, касающееся катетеров, из которых 80\% (97 патентов) принадлежит нерезидентам.

Распределение патентной активности в области шприцев и катетеров представлено в табл. 4.

Заметим, что упомянутая выше фармацевтическая компания Sanofi за последние 5 лет получила 77 патентов на изобретения в области шприцев на территории РФ. То есть $1 / 4$

\section{Распределение патентной активности резидентов и нерезидентов РФ в области шприцев и катетеров}

\begin{tabular}{|c|c|c|c|c|}
\hline \multirow{2}{*}{ Год } & \multicolumn{2}{|c|}{$\begin{array}{c}\text { Количество патентов РФ, } \\
\text { полученных нерезидентами }\end{array}$} & \multicolumn{2}{|c|}{$\begin{array}{l}\text { Количество патентов РФ, } \\
\text { полученных резидентами }\end{array}$} \\
\hline & Изобретение & Полезная модель & Изобретение & Полезная модель \\
\hline \multicolumn{5}{|c|}{ Шприцы } \\
\hline 2013 & 36 & 5 & 2 & 22 \\
\hline 2014 & 42 & 2 & 11 & 17 \\
\hline 2015 & 61 & 2 & 2 & 13 \\
\hline 2016 & 72 & 1 & 5 & 14 \\
\hline 2017 & 72 & 3 & 8 & 14 \\
\hline \multicolumn{5}{|c|}{ Катетеры } \\
\hline 2013 & 14 & 1 & 2 & 12 \\
\hline 2014 & 12 & 0 & 5 & 8 \\
\hline 2015 & 19 & 0 & 3 & 5 \\
\hline 2016 & 23 & 0 & 5 & 3 \\
\hline 2017 & 22 & 0 & 8 & 5 \\
\hline
\end{tabular}

Источник: БД ФИПС, данные актуальны на 10.06.2018 г. 
всех зарегистрированных за последние 5 лет патентов на шприцы, принадлежит Sanofi. Это демонстрирует прочную монопольную позицию данной компании на территории РФ, и создает для отечественных разработчиков высокие риски в продвижении на рынок в данной области.

В представленный в табл. 4 анализ были включены как изобретения, так и полезные модели. Различие указанных объектов охраны заключается в следующем. Экспертиза изобретений включает оценку патентоспособности разработки по трем условиям - промышленная применимость, новизна, изобретательский уровень (статья 1350 Гражданского Кодекса Российской Федерации [4]). Экспертиза полезных моделей включает оценку патентоспособности разработки по двум условиям промышленная применимость и новизна (статья 1351 Гражданского Кодекса). Еще одном отличием является то, что в случае судебных споров, только для изобретений используется доктрина эквивалентов.

Так, согласно пункту 3 статьи 1358 Гражданского Кодекса:

Изобретение признается использованным в продукте или способе, если продукт содержит, а в способе использован каждый признак изобретения, приведенный в независимом пункте содержащейся в патенте формулы изобретения, либо признак, эквивалентный ему и ставший известным в качестве такового в данной области техники до даты приоритета изобретения.

Полезная модель признается использованной в продукте, если продукт содержит каждый признак полезной модели, приведенный в независимом пункте содержащейся в патенте формулы полезной модели.

Таким образом, по сути, полезная модель подразумевает устройство, основанное лишь на незначительном усовершенствовании известного аналога. Кроме того, использование такого объекта патентной охраны делает разработку весьма уязвимой, т.к. позволяет ее легко обойти в рамках судебных споров.

Из представленных в табл. 4 данных следует, что иностранных изобретателей традиционно мало интересует защита своих разработок в качестве полезных моделей, а для отечественных же разработчиков этот вид охраны является весьма привлекательным.

Это можно объяснить тем, что сами разработчики не относят свои разработки к прорывным, формирующим новый технологический уклад, имеющим потенциал создания товаров и услуг качественно новой направленности.

Необходимо отметить, что объект «изобретение» обеспечивает охрану разработки на 20 лет. Это указывает на то, что 283 патента на шприцы и 91 патент на катетеры, полученные иностранными разработчиками, в течение ближайших, как минимум, 10 лет смогут быть препятствием для производства отечественной продукции и причиной патентных споров с отечественными производителями.

Еще одним отличием патентной охраны отечественных и зарубежных правообладателей является статус патентообладателя - юридическое или физическое лицо. В табл. 5 и 6 представлен список отечественных патентообладателей, имеющих 3 и более патентов на изобретения.

Согласно табл. 5, за последние 5 лет отечественные изобретатели получили 2 патента на изобретение и 4 патента на полезную модель. Для сравнения, за этот период нерезиденты РФ получили 118 патентов РФ на инсулиновые шприцы и 1 патент РФ на полезную модель.

Как уже было отмечено выше, фармацевтическая компания Sanofi за последние 5 лет получила 77 патентов РФ на изобретения в области шприцев. Причем 65 патентов РФ (85\%) касаются шприцев для инсулина, т.е. компания Sanofi является лидирующей компанией-нерезидентом, имеющей монополию на территории РФ на производство инсулиновых шприцев.

Ситуация, складывающаяся на рынке интеллектуальной собственности на территории РФ, в области инсулиновых шприцев такова: 2 патента на изобретение резидентов РФ против 118 патентов нерезидентов.

Согласно табл. 5, лидером в разработке шприцев в РФ является образовательное учреждение - Тверской государственный медицинский университет, для которого 


\section{Ton-7 отечественных патентообладателей инсулиновых шприцев по рассматриваемым классам $3 а 5$ лет}

Таблица 5

\section{Патентообладатель}

ООО «Уральский центр биофармацевтических технологий»

ООО «Континенталь-мед»

ООО «Уральский центр биофармацевтических технологий»,

ООО «Завод Медсинтез»

ООО «Смарт инновации»

Сеид-Гусейнов А.А., Созыкин А.В.

Симоненко С.В.

Белгородский государственный национальный исследовательский университет

Источник: БД ФИПС, данные актуальны на 10.06.2018 г.
Количество патентных документов РФ Изобретения Полезные модели

\section{Ведущие отечественные патентообладатели (имеющие 3 и более патентов) на шприцы различного назначения по рассматриваемым классам 395 лет}

\begin{tabular}{l|c|c|}
\multicolumn{1}{c|}{ Патентообладатель } & \multicolumn{2}{c|}{ Количество патентных документов } \\
\cline { 2 - 3 } & Изобретения & Полезные модели \\
\hline Тверской государственный медицинский университет & 3 & 5 \\
\hline ОО «Биофизическая аппаратура» & - & 4 \\
\hline Тюменский государственный университет & - & 4 \\
\hline Мишкин А.С. & - & 3 \\
\hline ООО Вирави & - & 3 \\
\hline
\end{tabular}

Источник: БД ФИПС, данные актуальны на 10.06.2018 г.

разработка медицинских изделий не является ключевым аспектом деятельности.

За последние 5 лет отечественные разработчики катетеров для сосудов, получили 2 патента на изобретение и 8 патентов на полезную модель. Для сравнения, за этот же период нерезиденты получили 51 патент на изобретение и 22 патента на полезную модель (табл. 7).

Для выявления отечественных юридических лиц, специализирующихся на производстве шприцев и катетеров, были проанализированы данные, представленные в Государственном реестре медицинских изделий и организаций (индивидуальных предпринимателей), осуществляющих производство и изготовление медицинских изделий. Согласно ч. 4 ст. 38 Федерального закона от 21.11 .2011 г. № 323-Ф3 «Об основах охраны здоровья граждан в Российской Федерации», на территории Российской Федерации разрешается обращение медицинских изделий, зарегистрированных в порядке, установленном Правительством Российской Федерации, уполномоченным им федеральным органом исполнительной власти. Таким уполномоченным федеральным органом исполнительной власти является Федеральная служба по надзору в сфере здравоохранения (http://www.roszdravnadzor.ru). Причем Росздравнадзор осуществляет ведение государственного реестра медицинских изделий и организаций, осуществляющих производство и изготовление медицинских изделий, и размещает его на своем официальном сайте в сети «Интернет».

В анализ были включены только инсулиновые шприцы и катетеры для сосудов.

Анализ сведений, представленных в государственном реестре медицинских изделий, позволил выявить: 


\section{Tоп-9 отечественных патентообладателей в области катетеров для сосудов по рассматриваемым классам 3а 5 лет}

\begin{tabular}{l|c|c|}
\multicolumn{1}{|c|}{ Патентообладатель } & \multicolumn{1}{|c}{ Количество патентных документов } \\
\cline { 2 - 3 } & Изобретения & Полезные модели \\
\hline ЗАО «МедСил» & & 1 \\
\hline Северо-Западный государственный медицинский университет & 1 \\
\hline Саратовский научно-исследовательский институт кардиологии & 1 \\
\hline Общество с ограниченной ответственностью «СемБиОс» & 1 \\
\hline Общество с ограниченной ответственностью «СП-Сфера» & 1 \\
\hline Зайцева Елена Николаевна, & \\
\hline Зайцев Андрей Русланович, & 1 \\
Дубищев Алексей Владимирович & \\
\hline Омский государственный медицинский университет & \\
\hline Андреев Юрий Германович, & \\
Рафф Леонид Семенович & & 1 \\
\hline Кавтеладзе Заза Александрович & & 1 \\
\hline
\end{tabular}

Источник: БД ФИПС, данные актуальны на 10.06.2018 г.

1) шесть отечественных организаций, осуществляющих производство таких медицинских изделий, как шприцы:

- ООО «МПК «Елец»» (Липецкая область, г. Елец);

- ООО «МЕДПРОМ БОБЕНИ ПРОДАКШЕН»

(Рязанская область, г. Кораблино);

- ООО «Научно-производственная фирма «ВИНАР» (Москва);

- ООО НПО «СМТ» (Новосибирская область, г. Бердск);

- ОАО «Прометей-плюс» (Липецкая область, г. Елец);

- ЗАО «Полимед-111» (Москва).

Перечисленные компании, осуществляют производство и реализацию шприцев, но не имеют патентов на изобретения или полезные модели.

2) три отечественных организации, осуществляющие производство таких медицинских изделий, как катетеры:

- Ангиолайн (г. Новосибирск)

- ЗАО «ДатчМедСил» (Московская область)

- Минимальноинвазивные технологии (Московская область, г. Железнодорожный) в настоящее время проходят регистрацию кардиологических катетеров в Росздравнадзоре.
Компания Ангиолайн имеет всего лишь два патента на устройства «Расширительное устройство для снижения избыточного внутриглазного давления» (патент РФ на полезную модель № 126593) и «Окклюдер» (патент РФ на полезную модель № 128101).

Остальные компании не имеют патентов.

Таким образом, существуют разработчики, которые патентуют свои идеи, но не регистрируют их в Росздравнадзоре, а значит и не вводят в промышленный оборот, а также разработчики, которые регистрируют изделия в Росздравнадзоре, а значит, вводят в оборот, но не патентуют их. Первые, по сути, останавливаются на начальном этапе инновационного цикла - выполняют НИР, а вторые - сразу переходят на этап производства, без предварительно проведенных НИР и НИОКР. При этом затраты усилий лишь на НИР без дальнейшего продвижения товара на рынок, можно считать лишь тратой ресурсов, а производство изделий без предварительных патентных исследований, можно считать игрой в «русскую рулетку», т.к. выпуск товара на рынок без патентных исследований, без патентной охраны, создает крайне высокие риски многолетних судебных разбирательств с производителями, которые запатентовали свои выпускаемые изделия. 


\section{ЗАКЛЮЧЕНИЕ}

Разработки в области шприцев и катетеров в настоящее время крайне востребованы на мировом рынке. Однако отечественный рынок не защищен и находится на грани принципиальной потери монополии на изобретения такого рода по всей территории Российской Федерации. Это является удручающим фактом еще и в связи с тем, что сахарный диабет и заболевания сердечно-сосудистой системы занимают первые места среди причин смертности и инвалидизации населения России.
Преодолеть складывающуюся ситуацию можно путем создания отечественными предприятиями собственных инновационных конкурентоспособных продуктов с выстраиванием грамотной стратегии их правовой охраны как в РФ, так и за рубежом.

Кроме того, изложенная выше ситуация, указывает на необходимость отечественным ученым, разработчикам, с самого начала реализации национального проекта «Наука» уделить особое внимание патентной охране своих разработок, т.к. в противном случае действительная реализация утвержденного курса развития отечественной науки будет сомнительной.

\section{ЛИТЕРАТУРА}

1. Указ Президента Российской Федерации от 1 декабря 2016 г. № 642 (2016) О стратегии научно-технологического развития Российской Федерации / Официальный сайт Президента России. http://www.kremlin.ru/acts/bank/41449.

2. Приказ Минпромторга России от 31 марта 2015 г. № 655 (2015) Об утверждении плана мероприятий по импортозамещению в отрасли медицинской промышленности Российской Федерации / Законодательство РФ. http://legalacts. ru/doc/prikaz-minpromtorga-rossii-ot-31032015n-655-ob-utverzhdenii.
3. Указ Президента Российской Федерации от 7 мая 2018 г. № 204 (2018) О национальных целях и стратегических задачах развития Российской Федерации на период до 2024 года / Официальный сайт Президента России. http://www.kremlin. ru/acts/bank/43027.

4. Гражданский кодекс Российской Федерации от 18 декабря 2006 г. № 230-Ф3 Часть четвертая (2006) / Консультант. http://www.consultant.ru/ document/cons_doc_LAW_64629.

\section{REFERENCES}

1. Order of the President of the Russian Federation dated 1 December 2016 № 642 (2016) On the Strategy of the Scientific and Technological Development of the Russian Federation / Official Website of the President of Russia. http://www.kremlin.ru/acts/bank/41449.

2. Order of the Ministry of Industry and Trade of Russia dated 31 March 2015 № 655 (2015) On approval of the plan of measures for import substitution in the medical industry of the Russian Federation / Legislation of the Russian Federation. http://legalacts.ru/doc/prikaz-minpromtorga-rossiiot-31032015-n-655-ob-utverzhdenii.
3. Order of the President of the Russian Federation dated May 2018 № 204 (2018) On the national goals and strategic objectives of the development of the Russian Federation for the period up to 2024 / Official Website of the President of Russia. http:// www.kremlin.ru/acts/bank/43027.

4. Civil Code of the Russian Federation dated 18 December 182006 № 230-FZ Part Four (2006) / Consultant. http://www.consultant.ru/document/ cons_doc_LAW_64629.

UDC 330.3

Erivantseva T.N. Syringes and catheters - prospects for overcoming import dependence in the context of the

implementation of the national project "Science" (Federal Institute of Industrial Property, Berezgkovskaya nab., 30,

к. 1, Moscow, Russia, 125993)

I Abstract. As part of the implementation of the approved presidential decrees "On the strategy of scientific and

I technological development of the Russian Federation" and the national project "Science", the Russian Federation should

I take leading positions in a number of scientific areas, including taking by 2024 the 5 th place in the amount of patent

I applications for inventions. The current patent activity of domestic developers in the field of devices for administering drugs

to the body or applying them onto the skin of a person is analyzed. A comparison study of inventive activity of domestic

and foreign developers is presented. The data obtained demonstrate the extremely low patent activity of domestic

1 developers compared with their foreign colleagues.

I Keywords: national project "Science", passport, number of requests for a patent, syringes, catheters. 